Reprod. Nutr. Dévelop., 1980, 20 (3 A), 735-745.

\title{
Influence of photoperiod on the time of parturition in the rat 1. - Effect of the length of daily illumination on normal or adrenalectomized animals
}

par M. J. BOSC, Agnès NICOLLE

Station de Physiologie de la Reproduction, I. N. R. A. Nouzilly 37380 Monnaie.

Summary. Four groups of normal rats have been studied to elucidate the effect on the time of birth of four different light regimes applied throughout pregnancy (day 1 : beginning of pregnancy). The results showed that the time of parturition (onset of expulsion) depended on the light treatment : the longer the duration of the daily illumination, the longer pregnancy lasted. With a 14 hrs light regime, the births occurred during two main periods : 50 p. 100 before 8 p.m. on day 22 of pregnancy and 36 p. 100 between 5 a.m. and 1 p.m. on day 23 . With $8 \mathrm{~h}$ of light per day, 69 p. 100 of the rats delivered before 9 p.m. on day 22 and 85 p. 100 before 5 a.m. of day of pregnancy. On the other hand, only 22 and 49 p. 100 of the rats gave birth at the same periods under a $20 \mathrm{hrs}$ light regime. Parturition under a completely dark photoperiod occurred mainly before day 23 of pregnancy and with a different rhythm than those of the preceding groups.

The influence of maternal adrenalectomy on the time of parturition was determined using two light regimes ( 14 or $20 \mathrm{hrs}$ of light per day). Under those conditions, the lenght of pregnancy was modified; parturition occurred earlier in adrenalectomized than in the normal rats submitted to the same light regime. These results suggest that the effect of light on the time of birth in the rat involves adrenal gland secretions.

The likelihood of birth is known to vary with the hour of the day ; this circadian aspect of parturition has often been related to environmental synchronizers such as light in mice (Long and Mark, 1911 ; Svorad and Sachova, 1959), horses (Rossdale and Short, 1967), pigs (Signoret, 1969) rats (Naaktgeboren and Slijper, 1970) and humans (Kaiser and Halberg, 1962). In the rat, a specific effect of light on the time of parturition has been suggested in experiments involving shifts of the light/dark cycle (Lincoin and Porter, 1976) or different lengths of daily illumination (Plaut et al., 1970 ; Mitchell and Yochim, 1970). However, the results observed under the latter conditions are not in agreement with those commonly observed under a standard light regime (Boer ef al., 1975 ; Cohen, 1976).

Attempis to establish if the pineal gland was involved in this effect of light in the rat have been unsuccessful (Mitchell and Yochim, 1970 ; Lincoln and Doyle, 1978), but involvement of the suprachiasmatic nuclei has been suggested (Lincoln and Doyle, 
1978). However, another possible cause of this influence of light on the time of parturition can be explained by modifications of the feto-maternal adrenal relationships. The ability of light to synchronize the secretions of corticosteroids and corticotropin is well documented in the rat (Krieger, 1974 ; Ixart et al., 1977). Parturition was found to occur invariably during the period when the corticosterone levels were minimal for two different photoperiodic treatments (Lincoln and Porter, 1979). Some studies have also suggested that these adrenal secretions play a role in the initiation of parturition (Yoshinaga, 1978), even if there are controversial interpretations as to the action of the fetal hypophyseal-adrenal axis on the duration of pregnancy in this species (Swaab et al., 1977). Metopirone which inhibits $11 \beta$ and 18 steroid hydroxylase activity, passes through the placenta (Dupouy, 1972) and leads to a prolongation of gestation (Parvez et al., 1972).

This experiment was undertaken to investigate the effects of the length of daily exposure to light on the time of birth in rats. In order to determine if the adrenals might be implicated, the effects of adrenalectomy of the mother were also studied under the same experimental conditions.

\section{Material and methods.}

a) Rats originating from the Wistar strain were used. They were kept in constanttemperature rooms $\left(4.5 \mathrm{~m} \times 2 \mathrm{~m} ; 22 \pm 1{ }^{\circ} \mathrm{C}\right)$ under cool white fluorescent lighting. The usual light regime was $14 \mathrm{hrs}$ of light and $10 \mathrm{hrs}$ of darkness (14L-10D) with the lights on from 6 a.m. to 8 p.m. The animals were housed 4 per box $(45 \times 30 \times 20 \mathrm{~cm})$ and the litter was changed twice a week. They had free access to food (U. A. A., Paris) and fresh water which was given daily except on Sunday. At 70 to 90 days of age, the females were caged with a male for 3 successive days. Successful mating was confirmed by the presence of spermatozoa in a vaginal smear. The mated animals were isolated on the day of mating (day 1 of pregnancy) in an individual box and assigned to an experimental group. Two to three mating sessions per group were needed; the females were used sequentially and allowed a maximum of two pregnancies.

b) Four groups were used to determine the influence of the length of the daily photoperiod on the time of parturition.

The light regimes were initiated on day 1 of pregnancy. The control group (group $C ; 78$ rats) was submitted to the usual regime of the colony (14L-10D).

Groups L (87 rats) and S (62 rats) were put under a long or short light regime, receiving $20 \mathrm{~h}(20 \mathrm{~L}-4 \mathrm{D})$ or $8 \mathrm{~h}(8 \mathrm{~L}-16 \mathrm{D})$ of light per day, respectively. The lights of group $L$ were switched on at 3 a.m. and those of group $S$ at 9 a.m. The fourth group (CD ; 66 rats) was kept in complete darkness and randomly reared (feeding, water, litter changes) during the working day to avoid rhythmic manipulation.

c) Two groups of adrenalectomized animals were compared with normal rats. One of them (group CA- ; 59 rats) was maintained under the control light regime (14L-10D) and the other (group LA- ; 41 rats) under the long-day regime (20L-4D). Adrenalectomy was performed before mating, and after surgery, only saline water $(9 \mathrm{~g} / \mathrm{l})$ was given. Only the animals in which the absence of adrenal tissue was verified, as previously described (Bosc and Nicolle, 1979), were retained for analysis. 
d) In all groups, the onset of pup expulsion was recorded. This moment is a good indication of the time of labour in the rat (Fuchs, 1969) since the duration of expulsion varies and seems independent of the day of parturition (Boer et al., 1975). The animals were monitored hourly during days 22 and 23 of pregnancy; a pocket lamp was used during the dark period. Thus, the beginning of parturition was determined by the hour preceding the observation of the first pups. The frequencies of parturition were expressed as the cumulative percentage of the 2-hour time intervals of days 22 and 23 of pregnancy. The distributions were then analyzed according to the non-parametric test of Kolmogoroff-Sirmnoff (Siegel, 1956). The total and surviving numbers of newborn rats were determined in each litter at the end of parturition. The rates of prolificy and stillbirth were compared by a Chi-square analysis (Snedecor and Cochran, 1957).

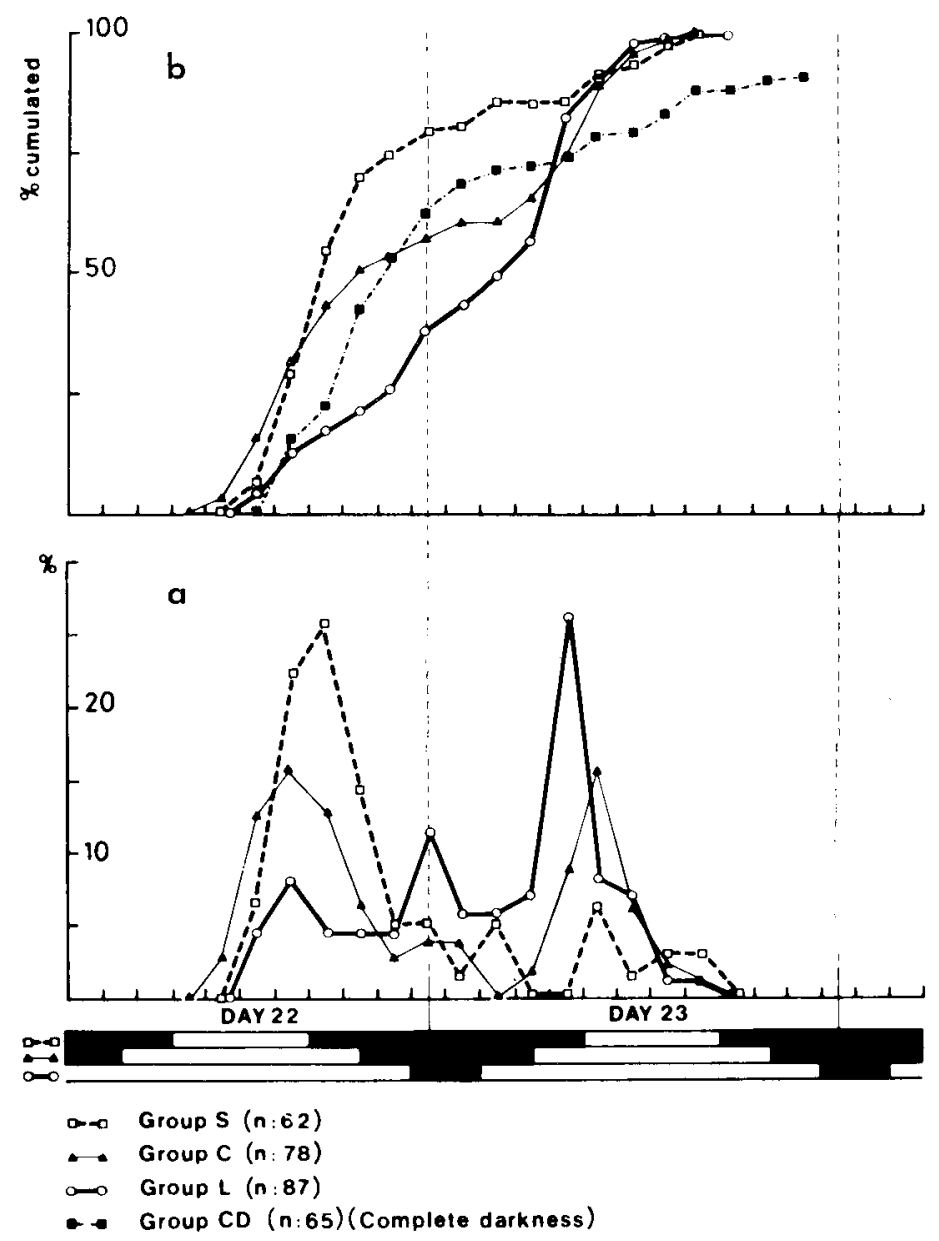

FIG. $1 a$ and $b$. - Time of parturition in the rat : Effect of applying four different daily light regimes throughout pregnancy. Group S (62 rats) : 8L-16D ; group C (78 rats) : 14L-10D ; group L (87 rats) : 20L-4D ; group CD (65 rats) : OL-24D. The disiributions are shown in frequencies in figure $1 a$ and in cumulative percentage in figure $1 b$. 


\section{Results.}

The distribution of parturitions in normal rats are presented in figure 1 (frequencies in fig. 1a, cumulative percentages in fig. $1 b$ ). Births under the control light regime (group $C ; 14 \mathrm{~L}-10 \mathrm{D}$ ) were concentrated in two main periods ; between $11 \mathrm{a.m}$. and 8 p.m. on days 22 of pregnancy $(50$ p. 100) and between 5 a.m. and 12 a.m. on day 23 (36 p. 100). In comparison, there was only one principal period under the short day (group $S ; 8 \mathrm{~L}-16 \mathrm{D}$ ) and the long-day (group L ; 20L-4D) light regimes. In group S, 69.4 and 85.5 p. 100 of the females delivered before 9 p.m. and before $5 \mathrm{a.m}$. on days 22 and 23 of pregnancy, respectively. In group $L$, the reverse situation was observed since only 21.8 and 49.3 p. 100 of the rats had given birth by those times. The figures for rats submitted to complete darkness (group CD) have only been plotted as cumulated frequencies (fig. $1 \mathrm{~b}$ ). In that group, 62 p. 100 of the deliveries occurred before 8 p.m. on day 22 of pregnancy, but 21.2 p. 100 of the animals went into labour after midday on

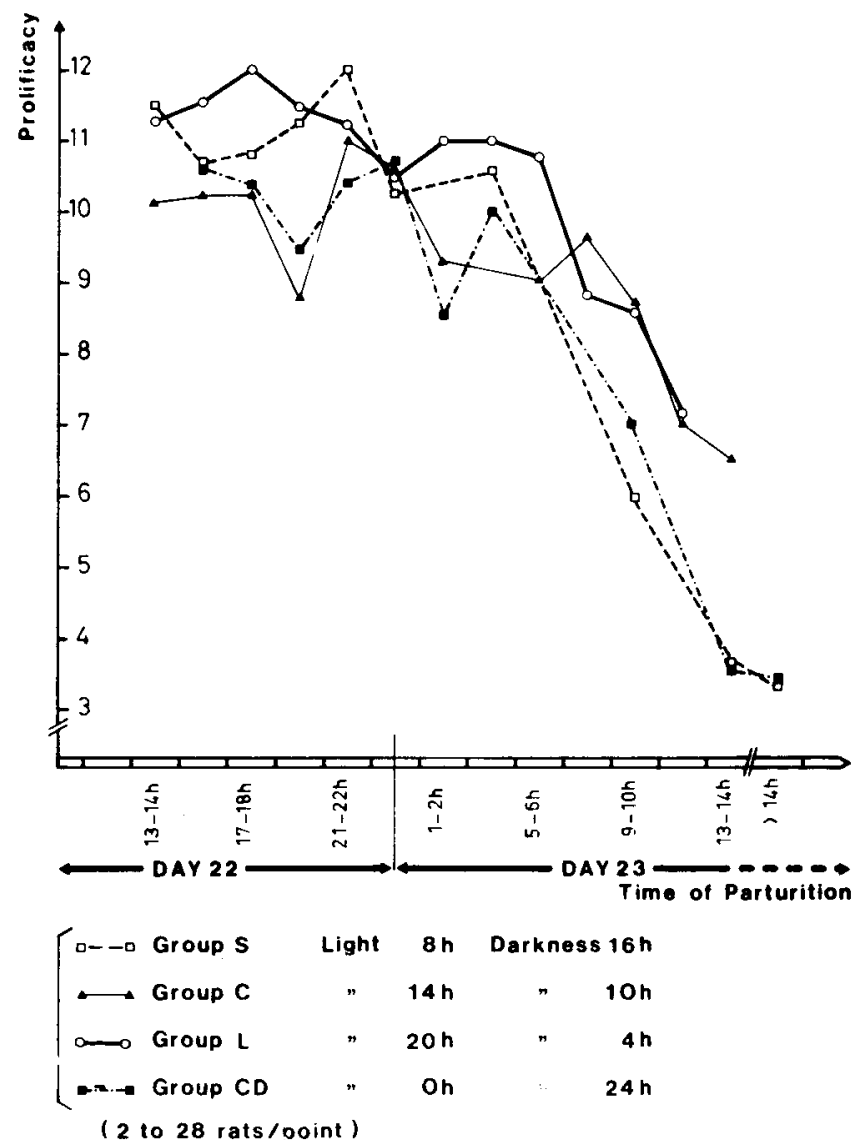

FIG. 2. - Mean prolificy in the rat according to the time of parturition and to the light regime applied during pregnancy. The number of rats per point varies depending on the time of birth and on the light regime, extremes : 2-28. 
day 23. A two-by-two comparison of these distributions showed that the time of parturition differed according to the group or the photoperiod $(P<0.05$ for groups $C$ vs $C D$ and $L$ vs $C D ; P<0.01$ for the others).

The stillbirth rate was not affected by the light regime $(P<0.05)$ but the litter size was not the same in each group $(0.01<P<0.05)$ (table 1$)$. In spite of that difference, mean prolificies showed similar patterns in regard to the time of parturition and the light regime (fig. 2). A pronounced decrease in litter size was observed on day 23 of pregnancy.

Parturition distributions in the adrenalectomized rats are presented in figure 3. Under the control light regime (14L-10D) parturition occurred earlier in the adrenalectomized rats (group CA-) than in the corresponding rats (group $C ; P<0.05$ ). Thus, 17.4 p. 100 of the adrenalectomized animals delivered before 11 a.m. and 51 p. 100

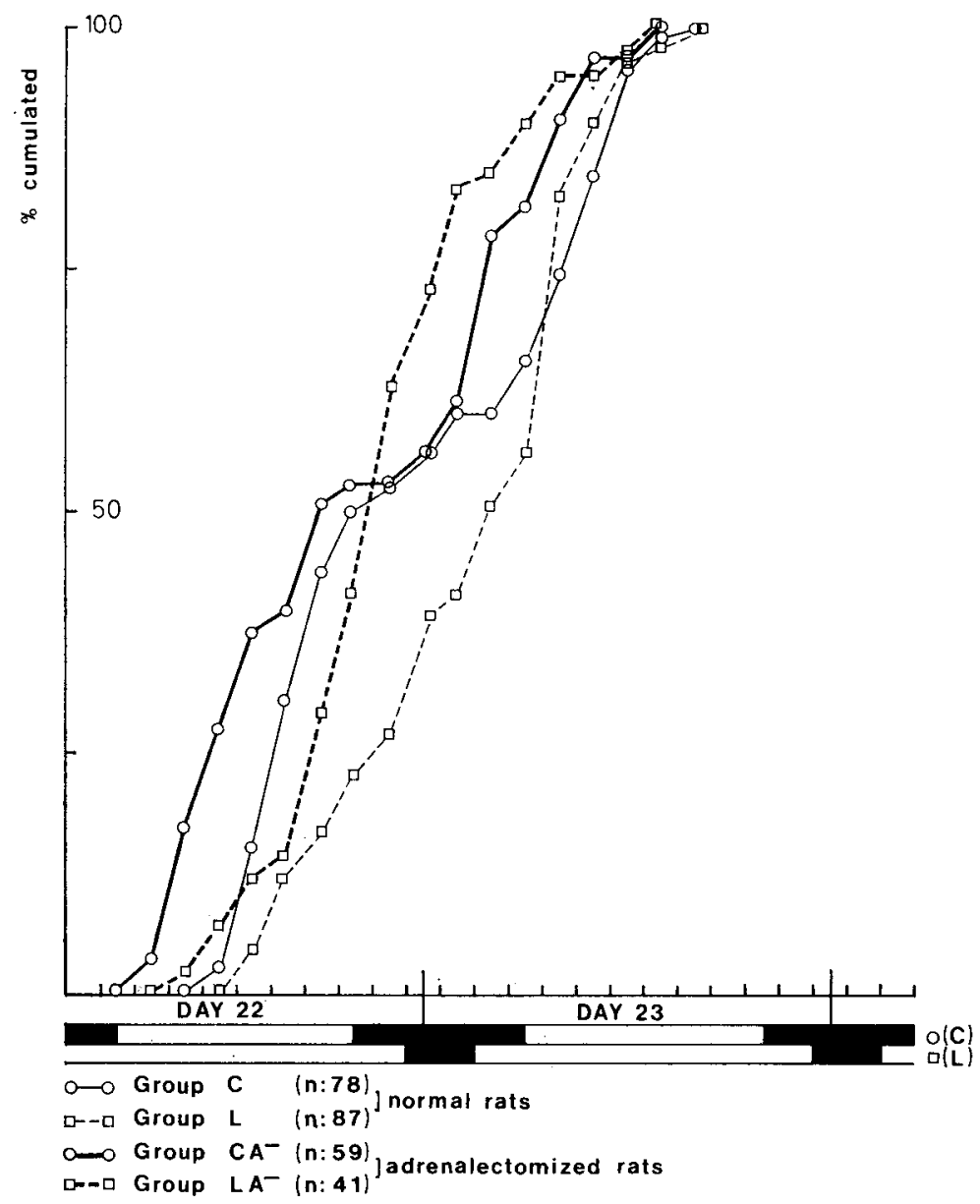

FIG. 3. - Time of parturition (cumulated frequencies) in the rat after adrenalectomy of the mother: Influence of two different light regimes. Group C (78 normal rats) and group CA (59 adrenalectomized rats) were subjected to $14 \mathrm{~L}-10 \mathrm{D}$ per day throughout pregnancy. Group $\mathrm{L}$ (87 normal rats) and group LA (41 adrenalectomized rats) received 20L-4D. 
before 7 p.m, on day 22 of pregnancy. 78.5 p. 100 of the parturitions occurred before $5 \mathrm{a} . \mathrm{m}$. on day 23 . The births were also distributed in two main periods which were advanced by about 3 to $4 \mathrm{hrs}$. Under the long-light regime (20L-4D), most of the adrenalectomized rats (group LA-) delivered before the normal rats subjected to the same treatment (group $L ; P<0.05$ ). Thus, 41,5 and 85.4 p. 100 of the parturitions of group LA- occurred before 9 p.m. on day 22 of pregnancy and before 5 a.m. on day 23 ; in comparison, 21.8 and 49.3 p. 100 of the rats of group $L$ gave birth at the same times. Litter size was not modified by adrenalectomy (table 1$)(P>0.05)$, but the stillbirth rate was higher than in the corresponding groups of normal rats $(P<0.01)$ (table 1$)$.

TABLE 1

Rates of prolificy and stillbirth in normal or adrenalectomized rats submitted to different photoperiods

\begin{tabular}{lcrr}
\hline Groups & Number of rats & $\begin{array}{c}\text { Prolificy } \\
(\mathrm{m}+\mathrm{sd})\end{array}$ & \multicolumn{1}{c}{$\begin{array}{c}\text { Stillbirth } \\
(\mathrm{p} .100)\end{array}$} \\
\hline $\mathrm{C} \ldots \ldots \ldots$ & 78 & $9.4+3.0$ & \\
$\mathrm{~S} \ldots \ldots \ldots \ldots$ & 62 & $10.0+2.9$ & 3.1 \\
$\mathrm{~L} \ldots \ldots \ldots$ & 87 & $9.9+2.9$ & 2.9 \\
$\mathrm{CD} \ldots \ldots \ldots$ & 65 & $8.5+3.5$ & 3.0 \\
$\mathrm{CA}-\ldots \ldots \ldots$ & 59 & $9.2+2.4$ & 4.4 \\
$\mathrm{LA}-\ldots \ldots$ & 41 & $9.4+2.6$ & 10.8 \\
& & & 11.9 \\
\hline
\end{tabular}

Groups $C, S, L$ and $C D$ : normal rats submitted to different photoperiods during the whole pregnancy.

C : control, 14L-10D ; S : short, 8L-16D ; L : long ; 20L-4D ; CD : complete darkness (OL-24D).

Groups $\mathrm{CA}^{-}$and $\mathrm{LA}^{-}$: adrenalectomized rats submitted to the control (C) or the long (L) photoperiod during pregnancy.

\section{Discussion.}

The time of parturition in the rat depends on the light regime, and the results indicate that the longer the photoperiod lasts, the longer is the length of pregnancy. The commonly-used median light regime (group C) is characterized by two main periods of parturition (Plaut et al., 1970 ; Boer ef al., 1975 ; Cohen, 1976 ; Lincoln and Porter, 1976), and the length of pregnancy is intermediate between the short (group S) and the long (group L) photoperiods. This apparently inhibitory effect of light, observed previously by Mitchell and Yochim (1970), appears to contradict the results obtained under complete darkness (group CD). However, in this study, group CD differs from the group submitted to a long photoperiod (group L). This disagrees with preceding observations (Plaut et al., 1970), but does not solve the problem arising from the comparison with the short-photoperiod group. In this experiment, whatever the group, the litter size was inversely related to the duration of pregnancy. Nevertheless, this fact only partially explains the fime-lag observed for the last deliveries of group CD which had the lowest prolificy. The mechanism by which light affects the time of parturition is not well known in the rat. It is thought that the time of implantation could play a role (Mitchell and Yochim, 1970) since a short (Lilit and Yeager, 1974) or a long (Yochim 
and Mitchell, 1970) photoperiod may affect the decidual sensitivity of the rat uterus. Implantation efficiency would be decreased when blastocyst development is asynchronous with uterine receptivity. In the present study, the time of implantation has not been taken into account. However, the absence of any difference in prolificy between most of the groups, or in the stillbirth rate, and the short time-lag between mating and implantation render an effect of light on parturition after implantation more probable. This is also sustained by the results of Lincoln and Porter (1976) who have noted changes in parturition times after a light shift applied at mid-pregnancy.

Parturition in the rat is the result of prostaglandin $F_{2 \alpha}\left(P F_{2 \alpha}\right.$ ) secretion (Chester et al., 1972 ; Labhsetwar and Watson, 1974 ; Dukes ef al., 1974 ; Buckle and Nathanielsz, 1975 ; Strauss ef al., 1975) which (i) abolishes the inhibition of uterine activity by progesterone (Deansley, 1956) and (ii) sustains labour (Dukes ef al., 1974 ; Labhsetwar and Watson, 1974 ; Shaikh ef al., 1977). The time of birth is therefore related to the time of the drop in progesterone concentrations which has been measured under different light regimes (Lincoln and Porter, 1979). The mechanism implied in the secretion of progesterone may be possibly regulated by environmental factors, such as light, which affect the time of delivery. During pregnancy, the corpora lutea are the main sites of progesterone production (Sanyal, 1978), the placenta (Sanyal, 1978) and the maternal adrenals being possible secondary sources (Mayer, 1978). Luteolysis, due to $\mathrm{PGF}_{2 \alpha}$, depends on oestrogen secretion by the ovaries (Yoshinaga et al., 1969 ; Waynforth et al., 1972 ; Labhsetwar and Watson, 1974) which, in turn, is controlled by the maternal pituitary (Acker, 1969 ; Waynforth and Robertson, 1972). The time of birth may be affected by light acting via this oestrogen production since a similar possibility has been suggested for other reproductive processes such as the oestrous cycle (Hoffmann, 1973 ; Hoffmann and Cullin, 1977 ; Takahashi et al., 1977). However, this interpretation has not been verified at the end of pregnancy (Porter et al., 1978). Another possibility is that progesterone secretion may be regulated by the maternal adrenals which can produce this steroid during pregnancy (Ogle and Kitay, 1977 ; Butterstein and Hirst, 1977 ; Mayer, 1978). The influence of light on the pituitary-adrenal axis is well known in the normal rat and the resulting circadian rhythms of corticotropin and corticosteroid secretions, due to the photoperiod, are well documented (Krieger, 1974 ; Ixart ef al., 1977). Such rhythms may also exist during pregnancy (Dupouy and Cohen, 1975). The levels of plasma corticosteroids are positively related to light intensity (Szafarczyk et al., 1971) or to the length of the daily light exposure (Krieger, 1974).

The adrenal secretion of progesterone can be stimulated by ACTH (Resko, 1969), depending on the hour of day, during the oestrous cycle (Mann and Barraclough, 1973) or at mid-pregnancy (Butterstein and Hirst, 1977). It is difficult to evaluate the production of adrenal progesterone during pregnancy, but it seems that the adrenal contribution to the maternal plasma levels of progesterone is low during pregnancy (Butterstein and Hirst, 1977 ; Legrand et al., 1979), although they can be significantly increased under stressful conditions (Ogle and Kitay, 1977) or after the administration of synthetic ACTH (Mayer, 1978). The possibility that the adrenal secretion of progesterone was affected under the light regimes applied in this experiment cannot be discarded. A more or less pronounced reduction in the duration of pregnancy after adrenalectomy, according to the light regime, agrees with this interpretation. 
However, the adrenals may be involved in another way in regulating the time of delivery under different photoperiods; this new interpretation involves the interactions between the foetal and maternal adrenals. Experiments using asynchronous implantation (Psychoyos ef al., 1966) or superimplantation (Yoshinaga, 1971) have shown that the foetuses produce positive factors for the initiation of parturition. Further evidence has been published showing that foetal corticosteroidogenesis plays an active role in this process (Parvez et al., 1972 ; Yoshinaga, 1978). In the rat, adrenalectomy of the mother leads to an increase of foetal adrenal weight (Ingle and Fisher, 1938 ; Walaas and Walaas, 1944 ; Angervall, 1962 ; Milkovic ef al., 1973 ; Klepac ef al., 1977) and to an augmentation in foetal corticosteroid concentrations (Thoman ef al., 1970 ; Milkovic et al., 1973 ; Cohen and Brault, 1974 ; Klepac et al., 1977 ; Arishima ef al., 1977). Conversely, the stimulation of maternal corticosteroid secretion reduces the development of foetal adrenal glands (Milkovic and Domac, 1973 ; Milkovic ef al., 1973) and decreases their in vifro steroidogenesis (Klepac et al., 1977). The decrease of the duration of pregnancy, observed after adrenalectomy, agrees with this interpretation; the decrease is more or less pronounced according to the light regime. This foetal role and the interactions between foeto-maternal adrenal functions provide an explanation for the inhibitory effect of light observed in our experiment, i. e. the shorter the daily photoperiod, the earlier the time of birth.

Reçu en oout 1979.

Accepté en décembre 1979.

Acknowledgements. - The authors are grateful to Mr. A. Beguey for the maintenance of animals, to Drs. P. Durand and R. Ortavant for their helpful comments and to Dr. J. Williams for the English presentation of this manuscript.

Résumé. L'influence de la durée journalière de la photopériode sur le moment de la naissance a été étudiée chez la ratte. Quatre lots d'animaux ont ainsi été constitués selon le régime lumineux auquel ils ont été soumis dès le début de la gestation (jour 1 de la gestation). Les résultats montrent que le moment de la naissance dépend du traitement lumineux, la durée de la gestation étant d'autant plus longue que la durée d'éclairement journalière est plus élevée. En effet, avec $14 \mathrm{~h}$ de lumière quotidienne, les parturitions se sont réparties en deux périodes principales avec 50 p. 100 d'entre elles avant $20 \mathrm{~h}$ du $22 \mathrm{e}$ jour de la gestation et 36 p. 100 entre 5 et $13 \mathrm{~h}$ du $23^{\mathrm{e}}$ jour. Avec $8 \mathrm{~h}$ de lumière par jour, 69 p. 100 des mise-bas se sont produites avant $21 \mathrm{~h}$ du $22^{\mathrm{e}}$ jour et $85 \mathrm{p} .100$ avant $5 \mathrm{~h}$ du $23 \mathrm{e}$ jour de la gestation ; par comparaison, seulement 22 p. 100 et 49 p. 100 des mise-bas ont été observées aux mêmes moments avec $20 \mathrm{~h}$ de lumière par jour. Les rattes placées sous obscurité complète mettent-bas principalement avant le $23^{\mathrm{e}}$ jour de la gestation selon un rythme différent des autres lots.

L'effet de la surrénalectomie maternelle sur le moment de la mise-bas a été étudié sous deux des régimes lumineux précédemment utilisés ( $14 \mathrm{~h}$ ou $20 \mathrm{~h}$ de lumière par jour). Dans ces conditions, la durée de la gestation a été chaque fois modifiée ; les naissances se produisant plus précocement après surrénalectomie par rapport à celles des rattes normales des lots correspondants. Ces résultats suggèrent que l'effet de la lumière sur le moment de la naissance met en jeu les sécrétions des surrénales. 


\section{References}

ACKER G., 1969. A propos du déterminisme hormonal de la mise-bas chez la rate ; rôle de l'œstradiol. C. R. Acad. Sci. Paris, Sér. D, 268, 2196-2199.

ANGERVALL L., 1962. Adrenalectomy in pregnant rats effects on offspring. Acta endocr., 41, 546560.

ARISHIMA K., NAKAMA S., MORIKAWA Y., HASHIMOTO Y., EGUCHI Y., 1977. Maternal fœtal interrelations of plasma corticosterone concentrations at the end of gestation in the rat. $J$. Endocr., 72, 239-240.

BOER K., LINCOLN D. W., SWAAB D. F., 1975. Effects of electrical stimulation of neurohypophysis on labour in the rat. J. Endocr., 65, 163-176.

BOSC M. J., NICOLLE A., 1979. Effect of a stress on the course of labour or on the time of parturition in normal or adrenalectomized rats. Ann. Biol. anim. Bioch. Biophys., 19, 31-44.

BUCKLE J. W., NATHANIELSZ P. W., 1975. A comparison of the characteristics of parturition induced by prostaglandin $F_{2}$ infused intraaortically with those following ovariectomy in the rat. J. Endocr., 64, 257-266.

BUTTERSTEIN G. M., HIRST J. A., 1977. Serum progesterone and fetal morphology following ovariectomy and adrenalectomy in the pregnant rat. Biol. Reprod., 16, 654-660.

CHESTER R., DUKES M., SLATER S. R., WALPOLE A. L., 1972. Delay of parturition in the rat by antiinflammatory agents which inhibit the biosynthesis of prostaglandins. Nalure, 240, 37-38.

COHEN A., 1976. Adrenal and plasma corticosterone levels in the pregnant, fotal and neonatal rat in the perinatal period. Horm. Metab. Res., 8, 474-478.

COHEN A., BRAULT S., 1974. Modifications de la concentration en corticostérone des surrénales ef du plasma chez le fœetus de rat après surrénalectomie maternelle. C. R. Acad. Sci. Paris, Sér. $D, 278,1755-1758$.

DEANSLEY R., 1956. The endocrinology of pregnant and fœtal life, 891-1063. In PARKES S. A., Marshall's Physiology of Reproduction, Vol. 3, Longmans, Green and Co, London.

DUKES M., CHESTER R., ATKINSON P., 1974. Effects of œstradiol and prostaglandin F $F_{2 \alpha}$ on the timing of parturition in the rat. J. Reprod. Fert., 38, 325-334.

DUPOUY J. P., 1972. Activité cortisostimulante de l'hypophyse du fœetus de rat après surrénalectomie maternelle et injection de métopirone à différents stades de la gestation. C. R. Acad. Sci. Paris, Sér. D, 274, 3585-3588.

DUPOUY J. P., COHEN A., 1975. Comparaison de l'activité corticosurrénalienne fœtale et maternelle au cours du nycthémère et durant la gestation. C. R. Acad. Sci. Paris, Sér. D, 280, 463-466.

FUCHS A. R., 1969. Uterine activity in late pregnancy and during parturition in the rat. Biol. Reprod., 1, 344-353.

HOFFMANN J. C., 1973. Light and reproduction in the rat. Effects of early lighting on responses measured in adult females. Biol. Reprod., 8, 473-480.

HOFFMANN J. C., CULLIN A. M., 1977. Effect of photoperiod length on feed back sensitivity to estradiol in the female rat. Neuroendocrinology, 23, 285-296.

INGLE D. J., FISHER G. T., 1938. Effect of adrenalectomy during gestation on the size of the adrenal glands of newborn rats. Proc. Soc. exp. Biol., 39, 149-150.

IXART G., SZAFARCZYK A., BELUGOU S. L., ASSENMACHER I., 1977. Temporal relationships between the diurnal rhythm of hypothalamic corticotrophin releasing factor ; pituitary corticotrophin and plasma corticosterone in the rat. J. Endocr., 72, 113-120.

KAISER I. H., HALBERG F., 1962. Circadian periodic aspects of birth. Ann. N. Y. Acad. Sci., 98, 10561068.

KLEPAC R., MILKOVIC K., MILKOVIC S., 1977. Development of steroidogenesis in the fetal rat adrenal gland : an in vitro study. J. Ster. Biochem., 8, 841-845.

KRIEGER D. T., 1974. Factors influencing the circadian periodicity of plasma corticosteroid levels. Chronobiologia, 1, 195-216.

LABHSETWAR A. P., WATSON D. J., 1974. Temporal relationship between secretory patterns of gonadotropins estrogens progestins and prostaglandin $\mathrm{F}_{2 \alpha}$ in periparturient rats. Biol. Reprod., 10, 103-110. 
LEGRAND C., SYN GUELAKIS M., EMMERICH A., ROBEL P., 1979. Relationships among placental, uterine and circulating concentrations of progesterone and fetal survival in the ovariectomized pregnant rat. Endocrinology, 105, 58-63.

LILIT N., YEAGER V. L., 1974. Effect of photoperiod on time of blastocyst implantation in the rat. Proc. Soc. exp. Biol. Med., 145, 894-896.

LINCOLN D. W., DOYLE J. C., 1978. Effect of pinealectomy and hypothalamic lesions on the hour of birth in rats. Abstr. 24, Proc. Soc. Stér. Fert., Annu. Conf., Cambridge.

LINCOLN D. W., PORTER D. G., 1976. Timing of the photoperiod and the hour of birth in rats. Nature, 260, 780-731.

LINCOLN D. W., PORTER D. G., 1979. Photoperiodic dissection of endocrine events at parturition. Anim. Reprod. Sci., 2, 97-115.

LONG J. A., MARK E. E., 1911. The maturation of the egg of the mouse. Cornegie Inst. Wash. Publ., 142, 1-72.

MANN D. R., BARRACLOUGH Ch. A., 1973. Changes in peripheral plasma progesterone during the rat 4-day estrous cycle; An adrenal diurnal rhythm. Proc. Soc. exp. Biol. Med., 142, 12261229.

MAYER G., 1978. Action de l'ACTH synthétique sur la gestation et la parturition chez la ratte. C. $R$. Acad. Sci. Paris, Sér. D, 286, 879-882.

MILKOVIC K., DOMAC B., 1973. The effect of fetal pituitary ACTH and maternal corticosteroids on the development of fetal rat adrenal cortex. Endocrinology, 62, 17-28.

MILKOVIC K., PAUNOVIC J., KNIEWALD Z., MILKOVIC S., 1973. Maintenance of the plasma corticosterone concentration of adrenalectomized rat by the fetal adrenal glands. Endocrinology, 93, 115-118.

MITCHELL J. A., YOCHIM J. M., 1970. Influence of environmental lighting on duration of pregnancy in the rat. Endocrinology, 87, 472-480.

NAAKTGEBOREN C., SLIJPER E. J., 1970. Biologie des Geburt Eine Ein-führung in die vergleichende Geburtskunde. Paul Parey, Hamburg und Berlin.

OGLE T. F., KITAY J. I., 1977. Ovarian and adrenal steroids during pregnancy and the cestrous cycle in the rat. J. Endocr., 74, 89-98.

PARVEZ S., PARVEZ H., ROFFI J., 1972. Gestation prolongée chez des rattes traitées par la métopirone. C. R. Acad. Sci. Paris, Sér. D, 274, 262-263.

PLAUT S. M., GROTA L. J., ADER R., GRAHAM C. W., 1970. Effects of handling and the light dark cycle on time of parturition in the rat. Lab. Anim. Care, 20, 447-453.

PORTER D. G., LINCOLN D. W., DOWNING S. J., HAAR B. T., CHALLIS J. R. G., KUHN N. J., HICKMAN-SMITH D., 1978. Identification of endocrinological changes related to the time of deliveries in rat. Abstr. 69, Proc. Soc. Ster. Fert. Annu. Conf., Cambridge.

PSYCHOYOS A., ALLOITEAU I. J., ACKER G., 1966. Delayed parturition in asynchronous implantation in the rat. !. Reprod. Fert., 12, 419-420.

RESKO J. A., 1969. Endocrine control of adrenal progesterone secretion in the ovariectomized rat. Science, 164, 70-71.

ROSSDALE P. D., SHORT R. V., 1967. The time of foaling of thoroughbred mares. J. Reprod. Fert., 13, 341-343.

SANYAL M. K., 1978. Secretion of progesterone during gestation in the rat. J. Endocr., 79, 179-190.

SHAIKH A. A., NAQVI R. H., SAKSENA S. K., 1977. Prostaglandins E and F in uterine venous plasma in relation to peripheral plasma levels of progesterone and 20-hydroxyprogesterone in the rat throughout pregnancy and parturition. Prostaglandins, 13, 311-320.

SIEGEL S., 1956. Non parametric statistics for the behavioral sciences. Int. Student ed., McGRAW-HILL Book Co Inc, Kogakusha Co Ltd.

SIGNORET J. P., 1969. Verhalten von Schweinen, 263-330. In PORZIG E., Das. Verhalten Landwirtschaftlicher nutztiere. Veb. Deutscher Landwirtschaftsverlag Berlin.

SNEDECOR G. W., COCHRAN W. G., 1957. Statistical methods 6th ed. (The lowa State Univ. Press), Ames, lowa, USA.

STRAUSS J. F., SOKOLOSKI J., CAPLOE P., DUFFY P., MINTZ P., STAMBAUGH R. L., 1975. On the role of prostaglandins in parturition in the rat. Endocrinology, 96, 1040-1043.

SVORAD D., SACHOVA V., 1959. Periodicity of the commencement of birth in mice and the influence of light. Physiol. bohemoslov., 8, 439-442. 
SZAFARCZYK A., BOISSIN J., ASSENMACHER I., 1971. Effets du niveau d'éclairement sur le rythme circadien de la cortisostéronémie chez la Ratte. C. R. Acad. Sci. Paris, Sér. D., 273, 2583-2586.

SWAAB D. F., BOER K., HONNEBIER W. J., 1977. The influence of the fetal hypothalamus and pituitary on the onset and course of parturition in The fetus and birth, Ciba Found. Symp. 47th ed., Elsevier Excerpta med., North Holland, Amsterdam.

TAKAHASHI M., FORD J. J., YOSHINAGA K., GREED R. O., 1977. Ovulation in light estrous rats induced by darkness. Endocrinol. jap., 24, 89-96.

THOMAN E. B., SPROUL M., SEELER B., LEVINE S., 1970. Influence of adrenalectomy in female rats on reproductive processes including effects on the foetus and offspring. J. Endocr., 46, 297-303.

WALAAS E., WALAAS O., 1944. Studies on the compensatory hypertrophy of the fetal adrenal glands in the albino rat produced by adrenalectomy during pregnancy. Acta pathol. microb. scand., 21, 640-672.

WAYNFORTH H. B., POPE G. S., HOSKING Z. D., 1972. Secretion rates of œstrogens into the ovarian venous blood of pregnant rats. J. Reprod. vert., 28, 191-196.

WAYNFORTH H. B., ROBERTSON D. M., 1972. Oestradiol content of ovarian venous blood and ovarian tissue in hypophysectomized rats during late pregnancy. J. Endocr., 54, 79-85.

YOCHIM J. M., MITCHELL J. A., 1970. Influence of environmental lighting on decidualization in the rat. Endocrinology, 87, 465-471.

YOSHINAGA K., HAWKINS R. A., STOCKER J. F., 1969. Estrogen secretion by the rat ovary in vivo during the estrous cycle and pregnancy. Endocrinology, 85, 103-112.

YOSHINAGA K., 1971. The role of fetus in the onset of parturition in the rat. Physiol., 14, 257.

YOSHINAGA K., 1978. The foetal pituitary adrenal axis in rat parturition. Abstr. 70, Proc. Soc. Ster. Fert. Annu. Conf., Cambridge. 